\title{
International Federation of Library Associations and Institutions - IFLA and Professional Associations in Serbia: The First 45 Years
}

\author{
Gordana Stokić Simončić \\ Belgrade University \\ Faculty of Philology - Library and Information Science Department \\ gordana.stokic.simoncic@gmail.com \\ Branka Dragosavac \\ Belgrade University \\ Faculty of Law - Library \\ branka.dragosavac@ius.bg.ac.rs
}

\section{Summary}

This work brings to life some new facts and presents the cooperation between the International Federation of Library Associations and Institutions (IFLA) and the associations of librarians in Serbia, in four and a half decades, between 1931 and 1976. In the period between the two world wars, this cooperation was established and maintained by the Yugoslav Library Association (1931-1940), especially its Belgrade Section, and after the Second World War it was realized through the Serbian Library Association (1948-1976) as a part of the Association of Librarians in Yugoslavia.

Yugoslavia, in the first period as a kingdom, and in the second as a socialist country, represents a state-legal framework to examine the phenomena of library associations and international cooperation. The Yugoslav Library Association was the predecessor of the Serbian Library Association, but under the new conditions of socialist construction, mentioning the organization from the previous, bourgeois period was undesirable. Nine years of the activity of the first professional library association in Yugoslavia were not evaluated in the right way: association that was founded later with the vast majority of former members and historians of librarianship, talked rarely about its existence, mainly for the political reasons.

Considering knowledge of the development of librarianship in national frameworks the basis for building a professional identity of librarians, the authors of this paper are trying to shed light on cooperation with IFLA as essential for maturing of the professional self-awareness. Taking into account that economic opportunities and political influences in the past decades have made this process difficult, the authors are trying to oppose their shared memory, common values, the feeling of belonging and self-respect as an identity property. Moreover, nowadays in Serbia there is a strong need for re-evaluation of the role and importance of library associations in order to reposition the profession, interrelations of professionals and modalities of voluntary work.

Keywords: librarians, professional associations, cooperation, Yugoslav Library Association (1931-1940), Serbian Library Association (1947- ), International Federation of Library Associations and Institutions (IFLA)

\section{Introduction}

Although nowadays Serbian librarians, at various levels and in various aspects, take an active part in the work of the International Federation of Library Associations and Institutions - IFLA only few of them know that professional cooperation with this organization lasts for over 85 years. ${ }^{1}$

\footnotetext{
1 The paper was written within the project Digital Media Technology and Socio-Educational Change, No. 47020, of the Ministry of Science and Technological Development of the Republic of Serbia.
} 
In spite of the fact that both archival and printed material (in Serbia and IFLA) testify about this cooperation, its range not only has not been evaluated, but it has never been presented in chronological order, which should precede the evaluation. Establishing chronology in cooperation Serbian librarians with IFLA is one of the goals of this paper.

Decades-long professional relations between Serbian librarians and IFLA were taking place in different state, political and economic frameworks: from the Kingdom of Yugoslavia through the Socialist Federal Republic of Yugoslavia and the Federal Republic of Yugoslavia to the Republic of Serbia. ${ }^{2}$ This paper deals with two periods - the first covers the time between the two world wars, and the other starts after the Second World War and ends in the eighties of $20^{\text {th }}$ century. As Serbian librarianship does not have a synthetic and analytical overview of professional ranges in the $20^{\text {th }}$ century, international cooperation, shaped through IFLA, is one of the possible aspects of observation.

Considering that the knowledge of the development of librarianship in national frameworks is the basis for building a professional identity of librarians, the authors of this paper are trying to shed light on the aspect of cooperation with IFLA as essential for maturing professional selfawareness. Taking into account that economic opportunities and political influences have aggravated this process in the past decades, they are trying to oppose their shared memory, common values, the feeling of belonging and self-respect as an identity property. This is more so today in Serbia there is a strong need to redefine the role of library associations and their significance for the position of profession, the mutual relations of professionals within the profession and the modalities of voluntary work.

The Archive of the Yugoslav Library Association, located in the University Library Svetozar Marković in Belgrade, was the main source for the beginning of research on cooperation with the International Federation of Library Associations (IFLA). ${ }^{3}$ The confirmation of this cooperation can also be found in the Reports of the International Library Committee and the IFLA Council (Actes du Comite International des Bibliotheques et du Conseil de la FIAB (Proceedings of the International Library Committee and of the Council of IFLA) $1932-1968,{ }^{4}$ stored at the headquarters of this organization in The Hague (The Netherlands), which have also been used in the work. In addition, a number of texts and reports were found in Bibliotekar (Librarian), the first post-war library journal of the Serbian Library Association (1947-), referring to the activities of Yugoslav librarians in the field of cooperation with IFLA, but also to the application of rules and standards incorporated in the work of domestic libraries of all types.

\footnotetext{
2 Yugoslavia was the name for three successive states in Southeast Europe, which ranged from 1929 to 2003 . The Kingdom of Serbs, Croats and Slovenes was established in 1918, and in 1929 it was renamed the Kingdom of Yugoslavia (sometimes known as the first Yugoslavia). During the Second World War, Yugoslavia was occupied by the Axis powers. In 1945, for a short time there was a Democratic Federal Yugoslavia, a formal monarchy, but already with the dominant republican order. On November 29 , 1945, the Federal People's Republic of Yugoslavia was declared - a federation of 6 republics and 2 autonomous provinces (known as the second Yugoslavia). The new Constitution was adopted in 1963, by which the country was renamed the Socialist Federal Republic of Yugoslavia. In the early 1990s, the SFRY broke up in the civil war, but the two former republics, Serbia and Montenegro, decided to continue the Yugoslav idea, and on April 27, 1992, the Federal Republic of Yugoslavia (the third Yugoslavia) was declared. On February 3, 2003, the constitutional charter of the State Union of Serbia and Montenegro was adopted, by which these two republics continued the existence of a common state for another three years (until the declaration of independence of Montenegro in May 2006), but the name "Yugoslavia" was canceled. - Yugoslavia, accessed May 9th 2019, https://sr.wikipedia. org/wiki//угославија.

3 Archive of the University Library Svetozar Marković in Belgrade, Archive of the Association of Yugoslav Librarians.

These are six boxes of material (marked 1, 2, 3, 4, 5, 8), and two notebooks $(6,7)$, continuously paginated, with labels and the inscription Archive of the Association of Yugoslav Librarians. The first five boxes contain materials, while the last contains the stamps of the Association. The two notebooks are in fact a register (6) and the meeting minutes of the General Administration of the Yugoslav Library Association 1931-1939 (7). It is interesting that the name on the labels i.e. boxes does not correspond to the official name of the Association, which we will hereafter use as the only relevant one. This could indicate some negligence of the person who placed the material in boxes. In the boxes themselves, on the folders, as well as on all documents, the name Yugoslav Library Association is used.

${ }^{4}$ This publication was the official gazette of the Organization between the two world wars, as well as after World War II.
} 


\section{Yugoslav Library Association and the International Federation of Library Associations and Institutions 1931-1939}

Yugoslav Library Association (YLA) started its work in mid-1931, after its three sections were created in Belgrade, Zagreb and Ljubljana, and it suspended activities in late 1939, after the resolution on the founding of the independent Croatian Library Association, adopted by the Zagreb Section. The Ljubljana Section was then liquidated, and the Belgrade Section continued its work until April 1940, when its administration held its last meeting.

The enthusiasm and momentum marking the beginning of the work of the Association (19311940) are amazing. Through the Rules of the Yugoslav Library Association, ${ }^{5}$ the main tasks and goals were set, ${ }^{6}$ two congresses of the Association were held (1931 and 19377), a law on public libraries was drafted, the need for the creation of a national bibliography and a central catalogue of books in Yugoslavia was prepared, printed material for the professional journals were collected, several professional monographs were published, cooperation with international associations was established etc.

The earliest document on the cooperation of the International and Yugoslav Library Association is stored in the IFLA archives in The Hague, dated December 15, $1931 . .^{8}$ It is a letter in which the president of the Yugoslav Library Association, Svetozar Matić, ${ }^{9}$ asks the president of IFLA, William Warner Bishop, to admit YLA into IFLA membership. The following year, Marija Ilić-Agapova, ${ }^{10} \mathrm{PhD}$, head of the Library and Museums of the Municipality of Belgrade, attended the IFLA congress in Bern.

From the Report of the Headquarter of the Belgrade Section for $1933,{ }^{11}$ we find out that Marija Ilić-Agapova, on February 18, within the series of educational programs for librarians, held a lecture on IFLA and her participation in the abovementioned congress. The first pages of her book Public Libraries, which appeared in 1934, are dedicated to the work of this international library association. Librarians and wider cultural public in Yugoslavia could read its short history, as well as the information about the proclaimed goals and IFLA meetings. The author also states that YLA was accepted as the $26^{\text {th }}$ member of this association. ${ }^{12}$

\footnotetext{
${ }^{5}$ Approved by the Ministry of Internal Affairs in Belgrade in November 1931 and published in 1932.

6 "The mission of the Association, defined by the rules, was work on improving library profession in the Kingdom of Yugoslavia, which will be a more successful help to science and education... The objectives of the Association are set and maintained: monitoring of the development of science about libraries and its branches; improvement of members and preparation of substudies through the establishment of library school and organization of periodic national courses and lectures; issuance of professional publications; contact with similar organizations in the country and institutions of importance for library activities to improve staff positions; work on issuing the yearbook of Yugoslav libraries; establishing and expansion of libraries in the country and providing help for their work; work on organizing libraries that should be performed in accordance with the regulations and requirements of modern trends in the profession; work on standardization of library jobs; realization of standby cooperation; providing professional opinions regarding the issues of the library and library staff; participation in international congresses of librarians and maintenance of links with professional organisations of librarians abroad." - Biljana M. Đurašinović, "Društvo jugoslovenskih bibliotekara: delovanje i dometi", Čitalište: naučni časopis za teoriju i praksu bibliotekarstva godina XIII, broj 25 (novembar 2014): 2-10, accessed June $24^{\text {th }} 2019$, http://citaliste.rs/casopis/br25/djurasinovic_biljana.pdf.

7 The first congress of the Association was held on November 28-29, 1931, in Zagreb. At that moment, the Association had 114 members: 65 from the Belgrade Section, 41 from Zagreb and 8 from Ljubljana. - The archives of the Yugoslav librarians, the report of the General administration of YLA in the year 1931-1937, submitted to the second Congress of the members.

The second congress of the YLA was held in Belgrade, on May 23, 1937. From the Zagreb Section there were 8 delagates, 4 from Ljubljana, and 32 from the Belgrade Section. -Đurašinović, „Društvo jugoslovenskih bibliotekara...: 6 .

8 IFLA Archiv, A letter to W.W. Bisoph.

9 Svetozar Matić (1887-1975), literary historian, lexicographer and translator; assistant manager of the National Library in Belgrade 1923-1941; member of the Belgrade Section YLA since 1931, with membership card number 3.

${ }_{10}$ Marija Ilić-Agapova (1895-1984) graduated on the Faculty of Law with a doctorate in Zagreb in 1923. She was the director of the Belgrade Public Library from 1932 to 1947. She was a member of the Belgrade Section of the Yugoslav Library Association since its establishment in 1931, in which she was active. In addition to works on librarianship, she wrote about Belgrade and translated dozens of books and texts.

11 Archive of the University Library Svetozar Marković in Belgrade, Archive of the Yugoslav Library Association.

12 Marija Ilić-Agapova, Javne biblioteke (Beograd: Biblioteka grada Beograda, 2003), 132.
} 
At the IFLA congress held in Madrid in 1935, there were Yugoslav representatives, too. They were Dragomir Arnautović1 13 , a librarian at the Ministry of Transport in Belgrade and Josip Badalić, ${ }^{14}$ a librarian at the University Library in Zagreb. Unfortunately, the IFLA archive contains information about their presence without a note about the conference presentation of Josip Badalić. However, in the Book of Records of the Belgrade Section, there is a strict evaluation written by Arnautović on Badalić's report prepared for IFLA which shows "idleness, mess and chaos in our libraries and in our country". Discussion that followed at the Belgrade session ended with the conclusion that delegates should give clear guidelines for the preparation of annual reports in the future. These reports were, from 1932 on, the usual way of informing and monitoring the state of national librarianship among member states, and the YLA also sent them to be read at annual IFLA meetings and then published in the Actes du Comite International des Bibliotheques et $d u$ Conseil de la FIAB. Melita Pivec Stele, PhD, another representative of the YLA in Bern, submitted a report for 1932; a very brief and unsigned report was sent in 1933; an unsigned but longer report for 1934 is preserved only in manuscript; the report for $1935 / 36$ was signed by Uroš Džonić, ${ }^{15}$ and the reports for 1937/38 and 1938/39 were signed by Josip Badalić.

Joining the international professional association, regular payment of membership fee, submitting annual reports, participation of YLA members at the IFLA sessions, monitoring the scope of the profession in more developed environments, promotion of international professional cooperation through professional lectures and publishing activities, are the main achievements of the Association at the international level. They are realized largely thanks to the work of the Belgrade Section. The Belgrade Section of the Yugoslav Library Association was the idea creator / founder of the Association, but also the main protagonist of the activities that it developed. The most numerous and most active, it has lasted the longest, and therefore can be considered as the holder of the YLA tradition.

"Judging by the professional actions initiated in complicated political and modest economic conditions - the period between the two world wars was the time of the ascension of Serbian librarianship, and the visions of the former librarians were built into the foundations of the afterwar development of the profession in our country". ${ }^{16}$ "Today, members of the library profession in Serbia can proudly reflect on this period and the first stage of library association: archival material undoubtedly confirms our right to move the date of establishment of the Serbian Library Association almost 20 years back, and as the date of its establishment we can take April 4, 1931, the date when Belgrade Section began its work". ${ }^{17}$

\section{Serbian Library Association and the International Federation of Library Associations and Institutions}

Since it ended the Second World War on the side of the victorious countries, with great losses in humanity and enormous material damage, Serbia began its development as a socialist country within Yugoslavia. The beginning of this period was marked by the political break of Yugoslavia

\footnotetext{
13 Dragomir Arnautovic (1883-1944), lawyer, doctorate in Sorbona with the topic History of Yugoslav Railways, 1937. He became a member of the YLA on March 1, 1935.

${ }^{14}$ Josip Badalić, doctor of Classical Philology and Slavic Studies, worked at the University Library in Zagreb 1919-1945. Badalić, Josip, Accessed July $7^{\text {th }}$ 2019, http://enciklopedija.hr/natuknica.aspx?id=5148.

15 Uroš Džonić (1887-1968) is a historian of literature, a professor at the Belgrade University; at the position of the administrator of the University Library in Belgrade from 1921 to 1941; member of the Belgrade Section YLA from 1931, with a membership card number 2 .

${ }^{16}$ Gordana Stokić Simončić, „Društvo jugoslovenskih bibliotekara i Bibliotekarsko društvo Srbije: kontinuitet profesionalnog udruživanja“, Čitalište: naučni časopis za teoriju i praksu bibliotekarstva godina XVI, broj 31 (novembar 2017): 56-61, accessed June 24 2019, http://citaliste.rs/casopis/br31/stokic_gordana.pdf.

17 Ibid.
} 
from the Soviet Union and the other socialist countries in 1948. The end of this period coincided with the fall of the Berlin Wall and the disintegration of the Yugoslav federation.

"Socio-political and economic circumstances in Yugoslavia and in the biggest of its six federal republics - Serbia - were quite different from those in other socialist countries. After the conflict with the Cominform ${ }^{18}$ in 1948 , Serbia began the process of reviewing and critiquing the model of a centralized, socially-planned economy and the bureaucratic model of the Communist Party. Serbia's search for its own identity led to the idea of self-governance, economic liberalization, and the democratization of social and cultural life. The country was modernizing rapidly and opening itself to western values and influences, which created the preconditions for the later modernization of librarianship, as well as the creation of new, professional library standards.

During the reconstruction of the war-torn country, the predominantly agrarian Serbian population was subject to a rapid process of industrialization that instigated a migration toward urban centers. Free education resulted in a rapid increase of educated Serbs and the ideological separation of the Eastern Bloc states created a climate of openness towards Western Europe and the United States of America. Yugoslavia began to enjoy for the first time an international reputation that surpassed its relative size and economic strength. Furthermore, as the founder and leader of the Non-Aligned Movement, Yugoslavia provided Serbia with a solid framework for the later development of its own educational and cultural institutions...

The political and social upheavals that occurred throughout the period between World War II and the Yugoslav wars provoked great changes in libraries. A more liberal flow of books, ideas, and information from abroad engendered a receptivity of Serbian librarianship toward European and international standards, trends, and professional values. International influences have, therefore, actively shaped Serbian librarianship in theory and practice as well as the professional organization of work within Serbian libraries and related library associations."19

In the period after World War II, Serbian librarianship first went through the phase of massive growth of readership and the number of libraries (1945-1960), then through the phase of stabilization of professional functions and normative legal foundation of activities (19611971), to start establishing a library information system in the third. The peak of the third phase seems to fall in the period 1971-1980, after which the weaknesses of the professional organization of librarians in Yugoslavia will be highlighted. However, during that decade, the centralized cataloguing of books for the entire territory of Yugoslavia began in the National Library of Serbia (1972), the National Library of Serbia became an IFLA member as an institution (1973), CIP was introduced (1976), and the implementation of the ISBD began (1977), which definitely laid the foundations for automation. In addition, for the first time, strategic documents on the development of library and information activities in Serbia were adopted. ${ }^{20}$

Serbian Library Association (1947-) was initiated as the result of the joint efforts of librarians affirmed during the interwar period and the enthusiasm that entered the profession

\footnotetext{
${ }^{18}$ Cominform (the Communist Information Bureau) was founded in 1947 with the purpose of coordinating the activities of the Communist parties under Soviet direction. The initial seat of Cominform was located in Belgrade, Serbia, which was at that time the capital of the Republic of Yugoslavia, but the Communist Party of Yugoslavia was expelled from the group in June 1948, after Stalin accused Tito of nationalism and moving toward the political right.

19 Gordana Stokić Simončić and Željko Vučković, "Searching for a Lost Identity: Serbian Librarianship at the Beginning of the Twenty-first Century", Library Trends (Libraries in the Postcommunist World: A Quarter of a Century of Development in Central and Eastern Europe and Russia: Part 1, edited by Hermina G. B. Angelescu) Volume 63, Number 2 (Fall 2014): 284-298. DOI: 10.1353/ lib.2014.0028, accessed May 24 ${ }^{\text {th }}$ 2018, http://muse.jhu.edu/login?auth=0\&type=summary\&url=/journals/library_trends/ v063/63.2.simoncic.html.

20 Projection of the Development of Librarianship in SR Serbia 1971-1980 and Librarianship Development Program 1971-1975 (Belgrade: Republic Union of the Parent Libraries of SR Serbia, 1971), represent the first attempt and effort to define and determine the basic directions of social action on the modernization and construction of librarianship in Serbia as a single and integrated system.
} 
immediately after the Second World War. Between the founders and the most prominent members of the new association were Milica Prodanović, Milica Vojinović, Ljudmila Mihailović, Irena Stefanović, Ivanka Piletić, Smilja Mišić, Radmila Čolaković, Ljubica Marković... Built on the experience of librarians from the previous period, the Serbian Library Association, as its most important task, proclaimed the creation and nurturing of professional staff at a time when libraries are being rapidly established in the country. The launch of a professional journal and a secondary school for librarians took place within 2-3 years after the establishment of the Association, and this efficiency can be explained by continuous work and pursuing the same objectives.

In 1949, the formerly formed professional associations of Serbia, Croatia and Slovenia founded new Yugoslav Library Association (YLA), which joined IFLA in $1950 .{ }^{21}$ In 1954 (September 27 - October 1), at the YLA invitation, the $20^{\text {th }}$ Council of IFLA was held in Zagreb "which was attended by 55 delegates from 25 associations - members, representing 16 countries and 4 international organizations" (UNESCO, FID, FAO, AIBM), "and 12 observers". It was attended by 6 delegates from Yugoslavia, and Serbia was represented by Milica Prodanović, manager of the University Library in Belgrade. ${ }^{22}$

By the end of the fifties of the last century, there were no Serbian contributors at IFLA congresses, but it is well known that at the meeting in Madrid (1958) SLA was represented by "Ljubinka Jovanović senior librarian at the University Library in Belgrade", ${ }^{23}$ while in Warsaw in 1959, Olga Milenović, Milica Prodanović and Ljubinka Jovanović attended and performed certain duties. Olga Milenović, a librarian from the Belgrade Theater Museum, which was delegated by the Foreign Relations Commission, actively participated in the work of the Section for Theater Libraries, while Ljubinka Jovanović "was the secretary of the commission for exchange of publications during its work and participated in the editorial board". ${ }^{24}$

In the sixties of the $20^{\text {th }}$ century, YLA and its members were not largely represented at IFLA meetings and conferences, with the exception of Croatian representatives, most notably Eva Verona, who had significant responsibilities and who, in Copenhagen in 1969, was entrusted with "the general editorial board of international rules for cataloguing." ${ }^{25}$

The next decade has made the most fruitful cooperation of YLA and SLA with IFLA. Namely, the number of delegates attending conferences during this period was reduced, but a considerable number of reports were presented.

At the Congress in Liverpool, in 1971, there were 13 delegates from Yugoslavia, 4 of them from Serbia, of whom even $3^{26}$ had reports. ${ }^{27}$

\footnotetext{
${ }^{21}$ Leposava Čukić i Bratislava Janjušević, „Međunarodna federacija bibliotečkih udruženja i institucija- IFLA“, Glasnik Narodne biblioteke Srbije 1, 1 (1999): 327-348, accessed June $1^{\text {st }}$ 2019, https://www.nb.rs/view_file.php?file_id=491.

22 Slobodan Petković, „Dvadeseto zasedanje Saveta Međunarodne federacije bibliotekarskih društava“, Bibliotekar 6, 4 (1954): 267.

23 Ljubinka Jovanović, "Sastanak FIAB-a u Madridu“, Bibliotekar 10, 4 (1958): 321-322

${ }^{24}$ Ljubinka Jovanović, "Dvadeset peti sastanak FIAB-a u Vašavi“, Bibliotekar 11, 3-4 (1959): 241-242.

25 Lidija Subotin, „XXXV zasedanje FIAB-a“, Bibliotekar 22, 1 (1970): 78.

${ }^{26}$ Radmila Nikolić-Bogdanović, "Uloga univerzitetskih biblioteka u procesu akademskog obrazovanja u Jugoslaviji: referat pripremljen za 37. Generalnu skupštinu IFLA-e u Liverpulu“, Bibliotekar 24, 1/2 (1972): 50-71.

The complete bibliography: Ismael Abdullahi, A Bibliography of IFLA Conference papers: 1968-1978 (Copenhagen: IFLA Clearinghouse; The Royal School of Librarianship, 1979) contains no information on this paper.

Svetislav Đurić, "Bibliotekarstvo u samoupravnom društvu: referat pripremljen za 37. Generalnu skupštinu IFLA-e u Liverpulu“, Bibliotekar 24, $1 / 2$ (1972): 33-49.

The complete bibliography A Bibliography of IFLA Conference papers: 1968-1978 contains no information on this paper.

Drago Vidović, „Budućnost bibliotekarstva i školovanje specijalista u bibliotekarskoj profesiji: referat pripremljen za 37. Generalnu skupštinu IFLA-e u Liverpulu“, Bibliotekar 24, 1/2 (1972): 72-80.

Drago Vidović, "The future of the Librarianship and the Education of Specialist in the Library Profession, in Abdullahi, A Bibliography of IFLA Conference papers: 1968-1978, 24

27 Drago Vidović, "37. Kongres IFLA-e u Liverpulu“, Bibliotekar 24, 1/2 (1972): 218-219.
} 
In 1972, in Budapest at the $38^{\text {th }}$ session of IFLA the following delegates from SLA presented their works: Desanka Stamatović, ${ }^{28}$ Piroška Čaki, ${ }^{29}$ Đorđe Vlajić ${ }^{30}$ and Slobodan Komadinić ${ }^{31} .{ }^{32}$

The most massive presence of YLA members was in Grenoble in 1973, as many as 20 librarians. ${ }^{33}$ The main topic of the session was dedicated to bibliographic control. There were 6 presentations from Yugoslavia, 4 of which were from Serbia. ${ }^{34}$ In addition, "In a separate meeting an initiative group of librarians from Mediterranean countries was established, in which D. Vidović took part". ${ }^{35}$

At the 1976 IFLA Congress, held in Lausanne, "the Yugoslav Library Association was presented with 9 experts, 4 of which were from the narrower Serbia", presented 3 papers. ${ }^{36}$ What is also very important to emphasize is that "the contributions, which were considered in the appropriate sections, were generally well received" (...), and that "the members of the delegation, in addition to the announcement, participated in plenary sessions and in the work of the relevant expert commissions". ${ }^{37}$

The participation of our representatives at IFLA, both in terms of the papers presented and their participation in its working bodies, had a great influence on the development of library theory and practice in our country and this was reflected in the "choice of topics discussed at regular professional meetings, congresses / Assembly of the Library Association of Yugoslavia", in terms of drafting standards for individual types of libraries, problems of universal bibliographic control, cataloguing, etc. ${ }^{38}$ That is so, especially since IFLA, in its annual congresses and working bodies, gathered an increasing number of members and offered a wide variety of participation

\footnotetext{
28 Desanka Stamatović , "The Future of the Book", in Reading in a Changing World, edited by Foster E. Mohrhardt (München: Verlag Dokumentation, 1976), 68-76.

Desanka Stamatović, „Budućnost knjige: knjiga i druga sredstva masovnih komunikacija“, Bibliotekar 24, 6 (1972): 705-714

Desanka Stamatovic, "The future of the Book: the book and other media of mass communication", in Abdullahi, A Bibliography of IFLA Conference papers..., 29

29 Pyroska S. Csaki, "The Hungarian book in Vojvodina", in Abdullahi, A Bibliography of IFLA Conference papers..., 25.

30 Djordje Vlajić, "Reading habits create reading needs", in Abdullahi, A Bibliography of IFLA Conference papers..., 30

31 Slobodan Komadinić, "The reading and bibliography in Yugoslavia" in Abdullahi, A Bibliography of IFLA Conference papers..., 27.

${ }^{32}$ Radmila Nikolić-Bogdanović, "38. zasedanje FIAB-a u Budimpešti“, Bibliotekar 24, 6 (1972): 773-774.

33 Čukić i Janjušević, „Međunarodna federacija bibliotečkih udruženja i institucija - IFLA“: 327-348.

${ }^{34}$ Slobodan M. Komadinić, "Current abstract on social sciences in Balkan countries", in Abdullahi, A Bibliography of IFLA Conference papers..., 33.

Radmila Nikolić-Bogdanović, "Univerzalna bibliografska kontrola i uključivanje univerzitetskih biblioteka u nacionalne sisteme informacija: referat održan na 39. zasedanju IFLA-e - Podsekcija za univerzitetske biblioteke, Grenobl, 1973.", Bibliotekar 25, 5/6 (1973): 549-557.

Radmila Nikolić-Bogdanović, "Universal Bibliographic Control and the Inclusion of University Libraries in National Information Systems" in Abdullahi, A Bibliography of IFLA Conference papers...,34.

Drago Vidović, „O razvoju uporednog bibliotekarstva u Jugoslaviji: referat podnet na 39. zasedanju IFLA-e u Grenoblu, 1973“, Bibliotekar 25, 5/6 (1973): 594-600.

Drago Vidović, "Problems in the Developing of Comparative Librarianship in Jugoslavia", in Abdullahi, A Bibliography of IFLA Conference papers..., 36.

Ljiljana Brković, „Univerzalna bibliografska kontrola i zakonska podloga za izradu nacionalne bibliografije: referat podnet na 39. zasedanju IFLA-e u Grenoblu, 1973“, Bibliotekar 25, 5/6 (1973): 543-548.

Ljiljana Brković, "The Universal Bibliographic Control and Legal Basis for the Compilation of the National Bibliography", in Abdullahi, A Bibliography of IFLA Conference papers...,31.

35 Drago Vidović, "39. zasjedanje IFLA u Grenoblu”, Bibliotekar 25, 5/6 (1973): 768-769.

${ }^{36}$ Perunika Popović-Ćićić, „Uloga biblioteka za fizičku kulturu u bibliotečko-informacionom sistemu u Jugoslaviji”, Bibliotekar 28, 5 (1976): 562-566

Perunika Popović-Ćićić, "The role of the library for physical culture within the library information system in Yugoslavia", in Abdullahi A Bibliography of IFLA Conference papers..., 49.

Drago Vidović, "Sadržaj i glavni pravci istraživačkog rada u području bibliotekarstva: informacije”, Bibliotekar 28, 5 (1976): 557-561. Drago Vidović, "Main directions and contest of library research in Yugoslavia", in Abdullahi, A Bibliography of IFLA Conference papers...,50.

Bogomila Živković, "Referalna delatnost u mreži biblioteka”, Bibliotekar 28, 5 (1976): 549-556.

Bogomila Živković, "Referral services in library networks", in Abdullahi, A Bibliography of IFLA Conference papers..., 50.

37 "Izveštaj o 42. Zasedanju IFLA-e od 23-28. avgusta 1976. Lozana“, Bibliotekar 28, 5 (1976): 702-704.

38 Čukić i Janjušević, „Međunarodna federacija bibliotečkih udruženja i institucija - IFLA“: 327-348.
} 
opportunities. Projects such as the Universal Accessibility of Publications, Universal Bibliographic Control and International Standards for the Description of Library Material have made it a leader and chief strategist in the development of world librarianship. In addition, it demonstrated political neutrality and internationalism, which was also manifested in cooperation with socialist countries and so-called countries of the Third World: the most massive gathering in history theretofore was held in Moscow in 1970, bringing together 747 librarians from different parts of the world. In 1974, IFLA had about 600 members from 100 countries. ${ }^{39} \mathrm{~A}$ year later, half of the member states were members of the Non-Aligned Movement. ${ }^{40}$

\section{Conclusion}

Encouraged by the increasing presence and participation of Serbian librarians in various activities of IFLA, the authors of this paper sought to shed light on the early decades of collaboration between the international professional organization and the Serbian Library Association. By now, it has been completely unknown to the professional public that the Yugoslavian Library Association became a member of IFLA as early as 1932 and that the cooperation between the two organizations is more than eight decades long. With the exception of the period 1939-1948, when IFLA itself suspended work due to World War II, this cooperation continued to grow until the last decade of the $20^{\text {th }}$ century.

The development of librarianship in Serbia before and after World War II was marked by attempts to establish strong links with the international professional community and to strengthen the identity of professionals in the country. But it was also marked by the internal political, economic and ideological circumstances that led to a slight stagnation in the last quarter of a century, followed by the collapse of all that had been achieved. However, this paper deals with a period that the authors consider to be a time of rise, growth, internationalization and international visibility. The period that followed is complex and under-researched in many ways, and should be subject to special analysis.

\section{Bibliography:}

1. Archive of the University Library "Svetozar Marković" in Belgrade. Archive of the Yugoslavian Library Association.

2. IFLA Archive.

3. $75^{\text {th }}$ anniversary brochure, 1927-2002. Accessed Oktober $10^{\text {th }}$ 2019. https://www.ifla.org/files/assets/hq/ history/ifla_2002_brochure.pdf.

4. Abdullahi, Ismael. A Bibliography of IFLA Conference papers: 1968-1978. Copenhagen: IFLA Clearinghouse; The Royal School of Librarianship, 1979.

5. Badalić, Josip. Accessed July $7^{\text {th }}$ 2019. http://enciklopedija.hr/natuknica.aspx?id=5148.

6. Brković, Ljiljana. „Univerzalna bibliografska kontrola i zakonska podloga za izradu nacionalne bibliografije: referat podnet na 39. zasedanju IFLA-e u Grenoblu, 1973“. Bibliotekar 25, 5/6 (1973): 543-548.

7. Čukić, Leposava i Bratislava Janjušević. „Međunarodna federacija bibliotečkih udruženja i institucija IFLA". Glasnik Narodne biblioteke Srbije 1, 1 (1999): 327-348. Accessed June $1^{\text {st }}$ 2019. https://www.nb.rs/ view_file.php?file_id=491.

$395^{\text {th }}$ anniversary brochure, 1927-2002, accessed October $10^{\text {th }} 2019$, https://www.ifla.org/files/assets/hq/history/ifla_2002_brochure.pdf

${ }^{40}$ Joachim Wieder, An Outline of IFLAs History, accessed June $1^{\text {st }} 2019$, https://www.ifla.org/files/assets/hq/history/ifla_first_50_reprise.pdf. 
8. Đurašinović, Biljana M. „Društvo jugoslovenskih bibliotekara: delovanje i dometi“. Čitalište: naučni časopis za teoriju i praksu bibliotekarstva godina XIII, broj 25 (novembar 2014): 2-10. Accessed June $24^{\text {th }}$ 2019. http://citaliste.rs/casopis/br25/djurasinovic_biljana.pdf.

9. Đurić, Svetislav. „Bibliotekarstvo u samoupravnom društvu: referat pripremljen za 37. Generalnu skupštinu IFLA-e u Liverpulu“. Bibliotekar 24, 1/2 (1972): 33-49.

10. Ilić-Agapova, Marija. Javne biblioteke. Beograd: Biblioteka grada Beograda, 2003.

11. „Izveštaj o 42. Zasedanju IFLA-e od 23-28. avgusta 1976. Lozana“. Bibliotekar 28, 5 (1976): 702-704.

12. Jovanović, Ljubinka. „Dvadeset peti sastanak FIAB-a u Vašavi”. Bibliotekar 11, 3-4 (1959): 241-242.

13. Jovanović, Ljubinka. "Sastanak FIAB-a u Madridu“. Bibliotekar 10, 4 (1958): 321-322.

14. Nikolić-Bogdanović, Radmila. „38. zasedanje FIAB-a u Budimpešti“. Bibliotekar 24, 6 (1972): 773-774.

15. Nikolić-Bogdanović, Radmila. „Uloga univerzitetskih biblioteka u procesu akademskog obrazovanja u Jugoslaviji: referat pripremljen za 37. Generalnu skupštinu IFLA-e u Liverpulu“. Bibliotekar 24, 1/2 (1972): 50-71.

16. Nikolić-Bogdanović, Radmila. „Univerzalna bibliografska kontrola i uključivanje univerzitetskih biblioteka u nacionalne sisteme informacija: referat održan na 39. zasedanju IFLA-e - Podsekcija za univerzitetske biblioteke, Grenobl, 1973.". Bibliotekar 25, 5/6 (1973): 549-557.

17. Petković, Slobodan. „Dvadeseto zasedanje Saveta Međunarodne federacije bibliotekarskih društava“. Bibliotekar 6, 4 (1954): 267-278.

18. Popović-Ćićić, Perunika. „Uloga biblioteka za fizičku kulturu u bibliotečko-informacionom sistemu u Jugoslaviji". Bibliotekar 28, 5 (1976): 562-566.

19. Projekcija razvoja bibliotekarstva u SR Srbiji od 1971-1980. godine i Program razvoja bibliotekarstva od 1971-1975. godine. Beograd: Republička zajednica matičnih biblioteka SR Srbije, 1971.

20. Stamatović, Desanka. „Budućnost knjige: knjiga i druga sredstva masovnih komunikacija“. Bibliotekar 24, 6 (1972): 705-714.

21. Stamatović, Desanka. "The Future of the Book". In Reading in a Changing World, edited by Foster E. Mohrhardt, 68-76. München: Verlag Dokumentation, 1976.

22. Stokić Simončić, Gordana and Željko Vučković. "Searching for a Lost Identity: Serbian Librarianship at the Beginning of the Twenty-first Century". Library Trends (Libraries in the Postcommunist World: A Quarter of a Century of Development in Central and Eastern Europe and Russia: Part 1, edited by Hermina G. B. Angelescu) Volume 63, Number 2 (Fall 2014): 284-298. DOI: 10.1353/lib.2014.0028. Accessed May $24^{\text {th }}$ 2018. http://muse.jhu.edu/login?auth=0\&type=summary\&url=/journals/library_trends/ v063/63.2.simoncic.html.

23. Stokić Simončić, Gordana. „Društvo jugoslovenskih bibliotekara i Bibliotekarsko društvo Srbije: kontinuitet profesionalnog udruživanja". Čitalište: naučni časopis za teoriju i praksu bibliotekarstva godina XVI, broj 31 (novembar 2017): 56-61. Accessed June 24th 2019. http://citaliste.rs/casopis/br31/stokic_gordana.pdf.

24. Subotin, Lidija. „XXXV zasedanje FIAB-a“. Bibliotekar 22, 1 (1970): 78-89.

25. Vidović, Drago. „37. Kongres IFLA-e u Liverpulu“. Bibliotekar 24, 1/2 (1972): 218-219.

26. Vidović, Drago. „39. zasjedanje IFLA u Grenoblu”. Bibliotekar 25, 5/6 (1973): 768-769.

27. Vidović, Drago. „Budućnost bibliotekarstva i školovanje specijalista u bibliotekarskoj profesiji: referat pripremljen za 37. Generalnu skupštinu IFLA-e u Liverpulu“. Bibliotekar 24, 1/2 (1972): 72-80.

28. Vidović, Drago. „O razvoju uporednog bibliotekarstva u Jugoslaviji: referat podnet na 39. zasedanju IFLA-e u Grenoblu, 1973“. Bibliotekar 25, 5/6 (1973): 594-600.

29. Vidović, Drago. "Sadržaj i glavni pravci istraživačkog rada u području bibliotekarstva: informacije". Bibliotekar 28, 5 (1976): 557-561.

30. Wieder, Joachim. An Outline of IFLAs History. Accessed June $1^{\text {st }}$ 2019. https://www.ifla.org/files/assets/ hq/history/ifla_first_50_reprise.pdf

31. Yugoslavia. Accessed May $9^{\text {th }}$ 2019. https://sr.wikipedia.org/wiki//угославија.

32. Živković, Bogomila. „Referalna delatnost u mreži biblioteka”. Bibliotekar 28, 5 (1976): 549-556. 


\title{
Међународна федерација библиотекарских удружења и институција - IFLA и професионална удружења у Србији: првих 45 година
}

\author{
Сажетак \\ Иако данас српски библиотекари на разним нивоима и у различитим видовима узимају активно учешће у раду \\ Међународне федерације библиотекарских удружења и институција - IFLA, само ретки међу њима знају да \\ професионална сарадња са овом организацијом траје преко 85 година. Премда о међусобној сарадњи сведоче и \\ архивска и штампана грађа (како у Србији, тако и у седишту IFLA-е у Хагу), њени домети не само да нису никада \\ оцењени, него никада нису представљени ни у хронолошком низу, што би морало претходити евалуацији. \\ Успостављање хронологије у сарадњи српских библиотекара ca IFLA-ом управо је један од циљева овог рада. \\ Вишедеценијски професионални односи српских библиотекара ca IFLA-ом одвијали су се у различитим \\ државним и политичко-економским оквирима: од Краљевине Југославије преко Социјалистичке Федеративне \\ Републике Југославије и Савезне Републике Југославије до Републике Србије. У овом раду разматрају се два \\ периода, онај између два светска рата и онај који се на њега надовезао, почевши након Другог светског рата и \\ достижући врхунац у осмој деценији 20. века. \\ Сматрајући да је познавање развоја библиотекарства у националним оквирима основа за изградњу \\ професионалног идентитета библиотекара, ауторке у овом раду настоје да по први пут осветле аспект сарадње \\ ca IFLA-ом, као суштински важан за сазревање професионалне самосвести. Имајући у виду да су економске \\ прилике и политички утицаји у претходним деценијама отежавали тај процес, оне настоје да им супротставе \\ заједничко памћење, заједничке вредности, осећање припадности и самопоштовања као својства идентитета.
}

Кључне речи: библиотекари, професионална удружења, међународна сарадња, Друштво југословенских библиотекара (1931-1940), Библиотекарско друштво Србије (1947-), Међународна федерација библиотекарских удружења и институција - IFLA 


\section{(c) $(1) \Theta(\Theta$}

International Federation of Library Associations and Institutions - IFLA and Professional Associations in Serbia: The First 45 Years by Gordana Stokić Simončić, Branka Dragosavac is licensed under a Creative Commons Attribution-NonCommercial-NoDerivatives 4.0 International License. 